\title{
TITIK KRITIS PELUNASAN SEBELUM JATUH TEMPO PEMBIAYAAN PROPERTI ; UPAYA MEWUJUDKAN PERLINDUNGAN KONSUMEN SEKTOR JASA KEUANGAN SYARIAH
}

\author{
Irham Fachreza Anas \\ Universitas Pamulang \\ irham_fachreza@yahoo.com
}

\begin{abstract}
Property Financing or KPR $i B$ is the provision of funds by the Sharia Bank for the purpose of property ownership as well as other consumption purposes that are property-backed. KPR iB's tenor is very varied even up to 25 years. Problems arise in the community related to repayment before maturity. Customer has a weakness in determining amount of repayment. One issue has been publicized and becoming a negative issue for Sharia Bank. Among the conclusions of this qualitative research are; i) calculation of repayment before maturity can be made using the Internal Rate of Return (IRR) and ii) the method calculating of repayment that reflecting the principle of benefit is principal balance pattern, the Rate of Return (RR) effective repayment must equal to the initial and iii) a repayment policy intended for the Good Customer.
\end{abstract}

Keywords : repayment before maturity, IRR, Benefit

\begin{abstract}
Abstrak
Pembiayaan Properti atau KPR iB adalah penyediaan dana oleh Bank Syariah untuk tujuan kepemilikan properti maupun tujuan konsumsi lainnya yang beragun properti. Tenor KPR iB sangat variatif bahkan hingga 25 tahun. Muncul persoalan di masyarakat terkait pelunasan sebelum jatuh tempo. Posisi tawar Nasabah dalam penetapan jumlah pelunasan lemah. Salah satu persoalan tersebut telah terpublikasi dan menjadi isu negatif bagi Bank Syariah. Di antara kesimpulan penelitian kualitatif ini adalah ; i) perhitungan jumlah pelunasan sebelum jatuh tempo dapat dilakukan dengan menggunakan Internal Rate of Return (IRR) dan ii) metode perhitungan jumlah pelunasan yang mencerminkan asas manfaat adalah pola saldo pokok dimana nilai Rate of Return atau RR efektif pelunasan harus sama dengan RR efektif awal dan iii) kebijakan pelunasan sebelum jatuh tempo ditujukan untuk Nasabah kategori Berprestasi.
\end{abstract}

Kata Kunci : Pelunasan Sebelum Jatuh Tempo, IRR, Manfaat 


\section{PENDAHULUAN}

Bank Syariah merupakan badan usaha yang berfungsi sebagai financial intermediary melalui kegiatan menghimpun dana dalam bentuk simpanan dan menyalurkan kembali dalam bentuk pembiayaan. Bank Syariah telah menjadi bagian sistem keuangan Indonesia sejak tahun 1992. Legitimasi Bank Syariah dalam Sistem Keuangan Indonesia dikuatkan dengan terbitnya Undang-Undang No. 21 tahun 2008 tentang Perbankan Syariah. Kegiatan bisnis Bank Syariah dalam perspektif Undang-Undang No. 21 tahun 2008 tunduk pada asas prinsip syariah, demokrasi ekonomi dan prinsip kehati-hatian.

Posisi Aset Perbankan Syariah di Indonesia pada 31 Desember 2017 tercatat sebesar Rp 435 triliun yang didukung dengan 201 Bank Syariah dan 2.610 jaringan kantor yang tersebar di seluruh wilayah Indonesia. Asset Share Bank Syariah terhadap Perbankan Nasional telah mencapai 5,47\%. Porsi pembiayaan dari total aset Bank Syariah adalah sebesar 67,01\% atau Rp 299,3 triliun. Produk pembiayaan konsumtif yang populer di masyarakat adalah pembiayaan properti atau jamak dikenal dengan 'KPR iB'.

KPR iB adalah penyediaan dana oleh Bank Syariah untuk tujuan kepemilikan properti maupun tujuan konsumtif lainnya yang beragun properti. Jenis properti yang dapat dimiliki dan/atau dijadikan agunan meliputi : Rumah Tapak, Rumah Susun dan Rumah Toko atau Rumah Kantor. Hal ini sebagaimana diatur dalam Peraturan Bank Indonesia (PBI) No. 18/16/PBI/2016 tanggal 26 Agustus 2016 Tentang Rasio Loan To Value Untuk Kredit Properti, Rasio Financing To Value untuk Pembiayaan Properti Dan Uang Muka Untuk Kredit Atau Pembiayaan Kendaraan Bermotor (selanjutnya ditulis "PBI No. 18/16/PBI/2016"). Dari sisi akad, KPR iB menggunakan akad Murabahah, Istishna', Ijarah Muntahiya Bittamlik (IMBT) dan Musyarakah Mutanaqishah (MMQ). PBI No. 18/16/PBI/2016 tidak mengatur tentang tenor atau jangka waktu pembiayaan sehingga memberikan kebebasan bagi Bank Syariah untuk menentukan sendiri tenor pembiayaannya. Berdasarkan penelusuran data elekronik, Bank Syariah bahkan menawarkan tenor sampai dengan 25 tahun, misalnya KPR iB Flexi CIMB Niaga.

Lamanya tenor KPR iB memiliki manfaat dan kelemahan. Manfaatnya adalah meringankan angsuran pembiayaan dan menambah limit pembiayaan. Sedangkan, kelemahannya adalah posisi tawar dalam penetapan jumlah pelunasan sebelum jatuh tempo atau pelunasan pembiayaan dipercepat lemah. Dari perspektif Hukum Islam dan Hukum Perdata, Bank Syariah memiliki posisi tawar yang kuat dalam menentukan jumlah pelunasan. Kelemahan ini dikhawatirkan dapat menjadi celah perselisihan antara Bank Syariah dan Nasabah.

Kekhawatiran itu terbukti. Bermula dari media sosial (baca ; facebook), publik pernah diramaikan dengan keluhan dari Nasabah KPR iB salah satu Bank Syariah, ${ }^{1}$ sebut saja Andi. Ia merupakan Nasabah KPR iB Murabahah dengan tenor 15 tahun yang berencana melakukan pelunasan sebelum jatuh tempo. Andi mempersoalkan

1 Harry Samsi. (2016). Ini Bukti Lingkaran Setan Kpr Bank. https://pospolitan.blogspot.co.id/2016/08/ini-bukti-lingkaran-setan-kpr-bank.html 
kebijakan Bank Syariah yang akan membebankan keseluruhan sisa harga jual murabahah (baca : piutang murabahah) kepadanya. Pihak Bank Syariah sebetulnya telah memberikan penjelasan lebih lanjut mengenai kemungkinan discount atau potongan pelunasan. Keluhan yang ditulis Andi berubah menjadi suara kebencian dengan kalimat sarkastik terhadap Bank Syariah. Tidak menutup kemungkinan persoalan yang sama terjadi pada Nasabah lain, namun belum ter-ekspose ke publik.

Kisah Andi merupakan keluhan terpublikasi yang menjadi isu negatif bagi Bank Syariah. Jika dibiarkan terakumulasi lama di tengah masyarakat tanpa solusi, tentu akan kontraproduktif terhadap upaya peningkatan literasi keuangan Nasional yang saat ini sedang gencar dipromosikan. Berangkat dari persoalan ini, Penulis tertarik melakukan penelitian lebih lanjut tentang pelunasan sebelum jatuh tempo pembiayaan sebagai solusi untuk melindungi kepentingan kedua belah pihak, yaitu Nasabah dan Bank Syariah dengan mengambil judul ; "Titik Kritis Pelunasan Sebelum Jatuh Tempo Pembiayaan Properti : Upaya Mewujudkan Perlindungan Konsumen Sektor Jasa Keuangan Syariah”

\section{KERANGKA TEORITIS}

\subsection{KPR iB Murabahah}

Murabahah adalah jual beli dengan harga perolehan dan tambahan keuntungan. ${ }^{2}$ Dalam Surat Edaran Otoritas Jasa Keuangan Nomor 36/SEOJK.03/2015 tanggal 21 Desember 2015 Tentang Produk dan Aktivitas Bank Syariah dan Unit Usaha Syariah (selanjutnya ditulis 'SEOJK No. 36/SEOJK.03/2015') pada Lampiran IV halaman 56, Pembiayaan Murabahah pada Bank Syariah adalah "Penyediaan dana atau tagihan yang dapat dipersamakan dengan itu untuk transaksi jual beli barang sebesar harga pokok ditambah margin berdasarkan persetujuan atau kesepakatan antara Bank dengan nasabah yang mewajibkan nasabah untuk melunasi hutang/kewajibannya".

\subsection{Pengakuan Keuntungan Flat, Efektif dan Anuitas}

Secara umum ada 2 (dua) metode perhitungan dan/atau pengakuan keuntungan (margin/fee/bagi hasil/bunga) pada transaksi keuangan yaitu flat dan efektif. Dalam praktiknya ada modifikasi lain yang kenal dengan metode anuitas. ${ }^{3}$

Dewan Syariah Nasional Majelis Ulama Indonesia (DSN-MUI) pada tanggal 21 Desember 2012 menerbitkan Fatwa No. 84/DSN-MUI/XII/2012 tentang Metode Pengakuan Keuntungan Al-Tamwil Bi Al-Murabahah (Pembiayaan Murabahah) Di Lembaga Keuangan Syariah. Fatwa ini mengatur tentang Metode Proporsional (flat) dan Metode Anuitas. Metode Proporsional (Thariqah Mubasyirah) adalah pengakuan keuntungan yang dilakukan secara proporsional atas jumlah piutang (harga jual, tsaman) yang berhasil ditagih dengan mengalikan

\footnotetext{
${ }^{2}$ Wahbah Al-Zuhaili. (2008). Al-Figh Al-islami Wa Adillatuhu, Juz 4. Damaskus. Dar Fikr al-Mu'asir. hal 491

${ }^{3}$ Brosur Bank Indonesia ; Memahami Bunga Kredit
} 
persentase keuntungan terhadap jumlah piutang yang berhasil ditagih (al-atsman al-muhashshalah). Sedangkan, Metode Anuitas (Thariqah al-Hisab alTanazuliyyah / Thariqah al- Tanaqushiyyah) adalah pengakuan keuntungan yang dilakukan secara proporsional atas jumlah sisa harga pokok yang belum ditagih dengan mengalikan persentase keuntungan terhadap jumlah sisa harga pokok yang belum ditagih (al-atsman al-mutabaqqiyah).

Pengakuan keuntungan al-Tamwil bi al-Murabahah dalam bisnis yang dilakukan oleh Lembaga Keuangan Syariah boleh dilakukan secara Proporsional dan secara Anuitas selama sesuai dengan 'urf (kebiasaan) yang berlaku di kalangan Lembaga Keuangan Syariah.

\subsection{Internal Rate of Return (IRR)}

Internal Rate of Return (IRR) atau Tinggal Laba Internal adalah tingkat laba yang membuat nilai sekarang arus kas di masa depan persis menyamakan investasi (awal). ${ }^{4}$ Metode ini akan menghitung suatu proyek dengan cara menyamakan nilai present value (saat ini) dari ekspektasi cash flow (arus kas) dan nilai investasi awal.

Fungsi IRR digunakan untuk mengetahui tingkat keuntungan dengan yang menyamakan nilai sekarang investasi (outflow) dengan nilai sekarang penerimaan kas bersih (inflow) di masa mendatang. Bentuk umum fungsi IRR dalam microsoft excel adalah : = IRR (range, perkiraan) ${ }^{5}$. Dengan range menyatakan arus kas. Perkiraan/guess diisi dengan sembarang nilai antara 0 dan 1 . Fungsi IRR melakukan perhitungan melalui proses iterasi (mencoba dan mendekati secara berulang). Jika setelah 20 kali interasi excel belum memperoleh hasil dengan ketelitian 0.0000001, fungsi itu memberikan pesan kesalahan \#NUM. ${ }^{6}$ IRR untuk KPR iB dengan aliran kas masuk bulanan harus dikalikan 12 atau di-setahun-kan. Fungsi IRR KPR iB berubah menjadi ; = IRR (range, perkiraan)*12.

\subsection{Perlindungan Konsumen Sektor Jasa Keuangan Syariah}

Perlindungan Konsumen dalam Undang-undang No. 8 Tahun 1999 adalah segala upaya yang menjamin adanya kepastian hukum untuk memberi kepada konsumen. Konsumen adalah setiap orang pemakai barang dan/atau jasa yang tersedia dalam masyarakat, baik bagi kepentingan diri sendiri, keluarga, orang lain maupun makhluk hidup lain dan tidak untuk diperdagangkan. Piranti hukum yang melindungi konsumen tidak dimaksudkan untuk mematikan usaha para pelaku usaha, tetapi justru sebaliknya perlindungan konsumen dapat mendorong iklim berusaha yang sehat yang mendorong lahirnya perusahaan yang tangguh dalam menghadapi persaingan melalui penyediaan barang dan/atau jasa yang berkualitas. Asas Perlindungan Konsumen sebagaimana Undang-undang No. 8 Tahun 1999 adalah ; Manfaat, Keadilan, Keseimbangan, Keamanan dan Keselamatan Konsumen dan Kepastian Hukum.

\footnotetext{
${ }^{4}$ Ciaran Walsh. (2012). Key Management Ratios. Edisi Keempat Penerjemah Agus Dharma. Jakarta. Esensi Erlangga Group. hal. 245

${ }^{5}$ Dalam Microsoft Excel 2010 formula IRR adalah = IRR (values;[ guess])

${ }^{6}$ Budianto, Aris. Modul Praktikum KKPI Microsoft Excel 2007 -Untuk Kelas : X Semester 2. Sidareja. SMK Tamtama 1 hal 39
} 
Otoritas Jasa Keuangan menetapkan Peraturan Otoritas Jasa Keuangan (POJK) No. 1/POJK.07/2013 tanggal 26 Juli 2013 Tentang Perlindungan Konsumen Sektor Jasa Keuangan. Peraturan yang diundangkan pada 06 Agustus 2013 tersebut mendefiniskan Perlindungan Konsumen sebagai perlindungan terhadap Konsumen dengan cakupan perilaku Pelaku Usaha Jasa Keuangan. Pelaku Jasa Keuangan dimaksud adalah Bank Umum, Bank Perkreditan Rakyat, Perusahaan Efek, Penasihat Investasi, Bank Kustodian, Dana Pensiun, Perusahaan Asuransi, Perusahaan Reasuransi, Lembaga Pembiayaan, Perusahaan Gadai, dan Perusahaan Penjaminan, baik yang melaksanakan kegiatan usahanya secara konvensional maupun secara syariah. Prinsip Perlindungan Konsumen dalam perspektif Otoritas Jasa Keuangan meliputi ; i) transparansi, ii) perlakuan yang adil, iii) keandalan, $i v$ ) kerahasiaan dan keamanan data/informasi Konsumen; dan v) penanganan pengaduan serta penyelesaian sengketa Konsumen secara sederhana, cepat, dan biaya terjangkau.

\subsection{Wa'd (Janji) Dalam Transaksi Keuangan Syariah}

$W a$ 'd adalah kesanggupan seseorang atau pihak tertentu untuk melakukan dan/atau tidak melakukan perbuatan tertentu. ${ }^{7} W^{\prime}$ ' $d$ juga berarti keinginan yang dikemukakan oleh seseorang untuk melakukan sesuatu, baik perbuatan maupun ucapan dalam rangka memberikan keuntungan bagi pihak lain. Dapat disimpulkan bahwa $W a$ 'd memiliki dua karakteristik utama, yaitu : dilakukan pada masa yang akan datang dan dilakukan oleh satu pihak. ${ }^{8}$

Dikutip dari Fatwa DSN-MUI No. 85/DSN-MUI/XII/2012, terdapat lima syarat agar wa'd dinyatakan mulzim (mengikat) sehingga wajib dipenuhi oleh pemberi janji. Meliputi ; i) Janji harus dinyatakan secara tertulis dalam akta atau kontrak perjanJIAn, ii) Janji harus dikaitkan dengan sesuatu (syarat) yang harus dipenuh atau dilaksanakan pemberi janji (janji bersyarat), iii) objek janji tidak bertentangan dengan syariah, iv) Dalam konteks janji bersyarat, maka syarat sebagaimana dimaksud tidak bertentangan dengan syariah dan $v$ ) Penerima Janji sudah memenuhi atau melaksanakan syarat sebagaimana huruf $i$ i).

$W a^{\prime} d$ sebanding dengan janji atau pernyataan pihak tentang kesanggupan untuk melakukan sesuatu atau tidak melakukan perbuatan tertentu (dalam hubungan kelembagaan antar organisasi sering dibuat perjanJIAn bersama / MoU). Sedangkan akad sepadan dengan perjanJIAn. Dengan demikian, Wa'd pada prinsipnya merupakan pernyataan kehendak secara sepihak untuk melakukan perbuatan atau tidak melakukan perbuatan tertentu. Sedangkan akad adalah kesepakatan (toestemming) para pihak yang berupa pernyataan kehendak untuk melakukan atau tidak melakukan perbuatan tertentu (ijab/offer) dan disetujui oleh pihak lainnya (qabul/acceptasi).

Dalam SEOJK No. 36/SEOJK.03/2015 pada Lampiran IV halaman 58-59 dinyatakan ; '4.10 Bank dapat memberikan potongan tagihan (cicilan) murabahah

\footnotetext{
7 Jaih Mubarok dan Hasanudin. (2017). Fikih Mu'amalah Maliyyah - Jilid Prinsip-Prinsip PerjanJIAn. Bandung. Simbiosa Rekatama Media. hal 2

8 Oni Sahroni, M. Hasanuddin. (2016). Fikih Muamalah ; Dinamika Teori Akad dan Implementasinya Dalam Ekonomi Syariah. Jakarta. Rajawali Press. Hal 3

${ }^{9}$ Jaih Mubarok. Op.Cit., hal 18-19
} 
yang belum dilunasi apabila nasabah melakukan pembayaran cicilan tepat waktu dan/atau mengalami penurunan kemampuan membayar, dengan syarat tidak boleh diperjanjikan dalam akad dan besarnya potongan diserahkan kepada kebijakan Bank. Dalam hal Bank memberikan potongan tagihan murabahah yang belum dilunasi karena nasabah membayar cicilan tepat waktu maka Bank harus memiliki kebijakan dan kriteria mengenai nasabah yang membayar cicilan tepat waktu. Mekanisme pemberian potongan tagihan murabahah mengacu pada Pedoman Akuntansi Perbankan Syariah Indonesia (PAPSI).'

Accounting and Auditing Organization for Islamic Financial Institutions (selanjutnya ditulis 'AAOIFI') membolehkan Lembaga Keuangan Syariah yang ingin melepaskan bagian keuntungannya sepanjang tidak diperjanjikan dalam perjanJIAn kontraktual (perjanJIAn pembiayaan). '5/9 It is permissible for the institution to give up part of selling price if the customer pays early, provided this was not part of the contractual agreement. ${ }^{10}$ DR. Erwandi Tarmizi menulis bahwa potongan harga kredit karena pelunasan sebelum jatuh tempo hukumnya boleh dengan syarat pemotongan harga tidak dicantumkan dalam akad jual-beli. Adapun alasan pelarangan pencantuman potongan pelunasan dalam akad sebagaimana dikutip dari bukunya berjudul Harta Haram Muamalat Kontemporer meliputi ; i) harga menjadi tidak jelas, sedangkan syarat sah jual beli harga dan barang harus jelas dan ii) akan terjadi riba jahiliyah dalam akad jual beli tersebut. Sebab, jika nasabah tidak jadi melunasi dipercepat maka harga jual menjadi naik. $^{11}$

\section{METODE RISET}

\subsection{Jenis, Pendekatan dan Model Penelitian}

Jenis penelitian ini adalah Penelitian Lapangan, yaitu penelitian yang bertujuan untuk mengumpulkan data dan informasi dengan bantuan berbagai macam material yang ada di lapangan (luar perpustakaan), yaitu penelitian pada Bank Syariah. Secara keseluruhan pendekatan penelitian yang digunakan adalah Empiris, yaitu meneliti kebijakan pelunasan sebelum jatuh tempo KPR iB yang dipraktikkan oleh Bank Syariah dan diakui oleh Nasabah.

Model penelitian ini adalah Kualitatif, yaitu penelitian yang tidak mengadakan penghitungan matematis, statistik dan lain sebagainya, melainkan menggunakan penekanan ilmiah ${ }^{12}$ atau penelitian yang menghasilkan penemuan-penemuan yang tidak dapat dicapai dengan menggunakan prosedur-prosedur statistik atau dengan cara-cara lain dari kuantifikasi. ${ }^{13}$ Bilamana dalam penelitian ini terdapat angkaangka, model perhitungan, dan lain sebagainya yang berhubungan dengan

10 Accounting and Auditing Organization for Islamic Financial Institutions. (2015). Shari'a Standards. Kingdom of Bahrain. hal 214

${ }^{11}$ Erwandi Tarmizi. (2016). Harta Haram Muamalat Komtemporer. Bogor. Berkat Mulia Insani. hal 458-459

${ }^{12}$ Lexy Moleong, (1997). Metodologi Penelitian Kualitatif ,ed: revisi. Bandung. PT Remaja Rosda Karya. hal. 6

${ }^{13}$ Syamsir Salam dan Jaenal Aripin. (2004). Metodologi Penelitian Sosial. Jakarta. UIN Jakarta Press. hal 30 
kuantitatif, maka hal tersebut dilakukan hanya sebatas untuk memperkuat analisis bukan untuk mencari hubungan antara variabel.

\subsection{Data, Pengumpulan Data dan Teknik Analisis}

Sumber data yang digunakan adalah primer dan sekunder. Data Primer bersumber dari Praktisi Bank Syariah, Nasabah KPR iB serta pihak lain yang berhubungan dengan judul penelitian. Sedangkan, Data Sekunder meliputi seluruh literatur yang berhubungan dengan instrumen keuangan, hukum Islam dan hukum positif yang berlaku dalam pembiayaan properti dan literatur lain yang dapat memberikan informasi tambahan pada judul yang diangkat dalam penelitian ini, misalnya ; brosur, artikel, berita dan lain sebagainya. Teknik pengumpulan data yang digunakan pada penelitian ini sebagai berikut ;

1) Studi Dokumentasi Naskah (studi pustaka) ; yaitu pengumpulan data dengan cara mengkaji Dokumen Kebijakan KPR iB salah satu Bank Syariah, Offering Letter / Surat Pemberitahuan Persetujuan Pembiayaan (SPPP) milik Nasabah KPR iB, Daftar Angsuran KPR iB, Fatwa DSN-MUI, POJK, Peraturan di Bidang Perlindungan Konsumen dan semua bahan tertulis lainnya, termasuk artikel yang diakses dari internet.

2) Wawancara ; dilakukan dengan melibatkan pihak-pihak yang dianggap kredibel atau punya keterkaitan dengan judul penelitian. Wawancara dilakukan dengan menggunakan Lembar Pedoman Wawancara. Adapun pihak-pihak yang dipilih sebagai responden meliputi : 1 orang dari Otoritas Jasa Keuangan (OJK), 1 orang dari Dewan Syariah Nasional Majelis Ulama Indonesia (DSN-MUI), 1 orang dari Akademisi Hukum Ekonomi Syariah, 1 orang dari Asosiasi Pengacara Syariah Indonesia (APSI), 9 orang praktisi Bank Syariah (Bagian Marketing/Kepala Unit/Kepatuhan) dan 4 orang Nasabah KPR iB.

Teknik analisa yang digunakan dalam penelitian kualitatif ini adalah Deskriptif Analisis. Deskriptif berarti teknik analisa dengan cara memberikan gambaran umum mengenai data penelitian meliputi ; perhitungan KPR iB, intisari wawancara dan ketentuan otoritas dan kebijakan pelunasan sebelum jatuh tempo pembiayaan atau pelunasan dipercepat (early payment). Gambaran data disusun berdasarkan kerangka pemikiran penulis. Gambaran data akan dianalisa secara kritis untuk menghasilkan kesimpulan dan solusi.

\subsection{Analisis Data}

Seluruh data yang berhasil diperoleh akan di susun ulang sehingga menyatu dalam bab dan/atau sub bab pembahasan. Berkaitan dengan permintaan kerahasiaan identitas pihak-pihak yang menjadi responden, maka analisa fakta dalam penelitian ini dibuat dengan tidak mencantumkan identitas diri Nasabah dan Praktisi serta nama Bank Syariah.

\subsubsection{KPR iB dengan Metode Pengakuan Keutungan Anuitas (Studi Kasus Pertama)}


1) Kasus pertama dialami oleh Andi. Ia dan Bank Syariah menandatangani PerjanJIAn KPR iB Murabahah dengan tenor 15 tahun. Nilai pembiayaan sebesar Rp 380.000.000,00. Harga jual rumah kepada Andi sebesar Rp 876.707.719,00. Diketahui Bank Syariah mengambil margin (keuntungan) sebesar Rp 496.707.719,00 atau rate of return / prosentasi tingkat keuntungan setara dengan $13,25 \%$ efektif per tahun.

2) Sesuai dengan perjanJIAn bahwa angsuran bulanan KPR iB adalah sebesar Rp 4.870.598,00. Dalam keluhannya, Anda menyertakan detail besaran penurunan cicilan pokok dan cicilan margin setidaknya selama bulan ke-1 sampai dengan bulan ke-29. Ia mengaku telah membayar angsuran selama 11 Bulan yaitu sekitar Rp 53.576.578,00.

3) Andi sebetulnya telah mendapat penjelasan dari Bank Syariah perihal mekanisme pengurangan pokok dan margin seperti piramida terbalik (akan lebih besar porsi pembayaran cicilan marjin ketimbang cicilan pokok dari angsuran yang ia bayar dalam beberapa bulan). Ini merupakan karakteristik dari metode pengakuan keuntungan Anuitas atau Thariqah al-Hisab alTanazuliyyah / Thariqah al- Tanaqushiyyah.

4) Andi berencana melakukan pelunasan sebelum jatuh tempo pada bulan ke12, Bank Syariah menjelaskan bahwa sesuai akad syariah Andi harus membayar sebesar Rp 823.131.136,00. Nilai itu berasal dari sisa angsuran pokok (Rp 372.907.009) dan sisa angsuran marjin ( $R p$ 450.977.211). Andi kemudian menyatakan, "Wah gila ini !!! Artinya dilunasin atau ga saya harus tetap membayar sesuai hitungan kredit 15 tahun”. Lebih lanjut, Bank Syariah memberikan penjelasan bahwa Andi dapat membayar sisa pokok Rp 372.907.009,00 dengan tambahan 3 bulan marjin sebesar Rp 12.302.285,00. Angka marjin ini diperoleh dari penjumlahan marjin bulan ke 12,13 dan 14 . 


\begin{tabular}{|c|c|c|c|c|c|}
\hline Bulan & O/S Pokok & Angs. Pokok & Angs. Margin & Total Angsuran & Ef. Rate \\
\hline & $380,000,000.00$ & & & $(380,000,000.00)$ & \\
\hline 1.00 & $379,325,234.89$ & $674,765.11$ & $4,195,833.33$ & $4,870,598.44$ & $13.25 \%$ \\
\hline 2.00 & $378,643,019.26$ & $682,215.64$ & $4,188,382.80$ & $4,870,598.44$ & $13.25 \%$ \\
\hline 3.00 & $377,953,270.82$ & $689,748.44$ & $4,180,850.00$ & $4,870,598.44$ & $13.25 \%$ \\
\hline 4.00 & $377,255,906.41$ & $697,364.41$ & $4,173,234.03$ & $4,870,598.44$ & $13.25 \%$ \\
\hline 5.00 & $376,550,841.94$ & $705,064.47$ & $4,165,533.97$ & $4,870,598.44$ & $13.25 \%$ \\
\hline 6.00 & $375,837,992.38$ & $712,849.56$ & $4,157,748.88$ & $4,870,598.44$ & $13.25 \%$ \\
\hline 7.00 & $375,117,271.77$ & $720,720.61$ & $4,149,877.83$ & $4,870,598.44$ & $13.25 \%$ \\
\hline 8.00 & $374,388,593.21$ & $728,678.56$ & $4,141,919.88$ & $4,870,598.44$ & $13.25 \%$ \\
\hline 9.00 & $373,651,868.82$ & $736,724.39$ & $4,133,874.05$ & $4,870,598.44$ & $13.25 \%$ \\
\hline 10.00 & $372,907,009.76$ & $744,859.05$ & $4,125,739.38$ & $4,870,598.44$ & $13.25 \%$ \\
\hline 11.00 & $372,153,926.22$ & $753,083.54$ & $4,117,514.90$ & $4,870,598.44$ & $13.25 \%$ \\
\hline 12.00 & $371,392,527.39$ & $761,398.84$ & $4,109,199.60$ & $4,870,598.44$ & $13.25 \%$ \\
\hline 13.00 & $370,622,721.44$ & $769,805.95$ & $4,100,792.49$ & $4,870,598.44$ & $13.25 \%$ \\
\hline 14.00 & $369,844,415.55$ & $778,305.89$ & $4,092,292.55$ & $4,870,598.44$ & $13.25 \%$ \\
\hline 15.00 & $369,057,515.86$ & $786,899.68$ & $4,083,698.75$ & $4,870,598.44$ & $13.25 \%$ \\
\hline 16.00 & $368,261,927.49$ & $795,588.37$ & $4,075,010.07$ & $4,870,598.44$ & $13.25 \%$ \\
\hline 17.00 & $367,457,554.50$ & $804,372.99$ & $4,066,225.45$ & $4,870,598.44$ & $13.25 \%$ \\
\hline 18.00 & $366,644,299.89$ & $813,254.61$ & $4,057,343.83$ & $4,870,598.44$ & $13.25 \%$ \\
\hline 19.00 & $365,822,065.60$ & $822,234.30$ & $4,048,364.14$ & $4,870,598.44$ & $13.25 \%$ \\
\hline 20.00 & $364,990,752.47$ & $831,313.13$ & $4,039,285.31$ & $4,870,598.44$ & $13.25 \%$ \\
\hline 21.00 & $364,150,260.25$ & $840,492.21$ & $4,030,106.23$ & $4,870,598.44$ & $13.25 \%$ \\
\hline 22.00 & $363,300,487.60$ & $849,772.65$ & $4,020,825.79$ & $4,870,598.44$ & $13.25 \%$ \\
\hline 23.00 & $362,441,332.05$ & $859,155.56$ & $4,011,442.88$ & $4,870,598.44$ & $13.25^{\circ}$ \\
\hline 24.00 & $361,572,689.98$ & $868,642.07$ & $4,001,956.37$ & $4,870,598.44$ & $13.25^{\circ}$ \\
\hline 175.00 & $23,566,632.86$ & $4,560,033.17$ & $310,565.27$ & $4,870,598.44$ & $13.25 \%$ \\
\hline 176.00 & $18,956,249.33$ & $4,610,383.54$ & $260,214.90$ & $4,870,598.44$ & $13.25 \%$ \\
\hline 177.00 & $14,294,959.48$ & $4,661,289.85$ & $209,308.59$ & $4,870,598.44$ & $13.25^{\circ}$ \\
\hline 178.00 & $9,582,201.21$ & $4,712,758.26$ & $157,840.18$ & $4,870,598.44$ & $13.25 \%$ \\
\hline 179.00 & $4,817,406.25$ & $4,764,794.97$ & $105,803.47$ & $4,870,598.44$ & $13.25^{\circ}$ \\
\hline 180.00 & $(0.00)$ & $4,817,406.25$ & $53,192.19$ & $4,870,598.44$ & $13.25 \%$ \\
\hline & TOTAL & $380,000,000.00$ & $496,707,719.15$ & $876,707,719.15$ & \\
\hline
\end{tabular}

Tabel 1 (Kasus Pertama) Perhitungan Angsuran dan IRR KPR iB Andi

\subsubsection{KPR iB dengan Metode Pengakuan Keutungan Flat atau Proporsional (Studi Kasus Kedua)}

1) Kasus kedua dialami oleh Budi. Ia dan Bank Syariah menandatangani PerjanJIAn KPR iB Akad Murabahah dengan tenor 10 tahun. Nilai pembiayaan sebesar Rp 272.565.000,00. Harga jual rumah kepada Budi adalah sebesar Rp 517.600,935,00. 


\begin{tabular}{|c|c|c|c|}
\hline Bulan & Saldo Awal & Angsuran & Saldo Akhir \\
\hline & & $(272,565,000.00)$ & \\
\hline 1 & $517,600,935.00$ & $4,313,341.13$ & $513,287,593.88$ \\
\hline 2 & $513,287,593.88$ & $4,313,341.13$ & $508,974,252.75$ \\
\hline 3 & $508,974,252.75$ & $4,313,341.13$ & $504,660,911.63$ \\
\hline 4 & $504,660,911.63$ & $4,313,341.13$ & $500,347,570.50$ \\
\hline 5 & $500,347,570.50$ & $4,313,341.13$ & $496,034,229.38$ \\
\hline 10 & $478,780,864.88$ & $4,313,341.13$ & $474,467,523.75$ \\
\hline 11 & $474,467,523.75$ & $4,313,341.13$ & $470,154,182.63$ \\
\hline 12 & $470,154,182.63$ & $4,313,341.13$ & $465,840,841.50$ \\
\hline 13 & $465,840,841.50$ & $4,313,341.13$ & $461,527,500.38$ \\
\hline 14 & $461,527,500.38$ & $4,313,341.13$ & $457,214,159.25$ \\
\hline 15 & $457,214,159.25$ & $4,313,341.13$ & $452,900,818.13$ \\
\hline 16 & $452,900,818.13$ & $4,313,341.13$ & $448,587,477.00$ \\
\hline 17 & $448,587,477.00$ & $4,313,341.13$ & $444,274,135.88$ \\
\hline 18 & $444,274,135.88$ & $4,313,341.13$ & $439,960,794.75$ \\
\hline 19 & $439,960,794.75$ & $4,313,341.13$ & $435,647,453.63$ \\
\hline 20 & $435,647,453.63$ & $4,313,341.13$ & $431,334,112.50$ \\
\hline 21 & $431,334,112.50$ & $4,313,341.13$ & $427,020,771.38$ \\
\hline 22 & $427,020,771.38$ & $4,313,341.13$ & $422,707,430.25$ \\
\hline 23 & $422,707,430.25$ & $4,313,341.13$ & $418,394,089.13$ \\
\hline 24 & $418,394,089.13$ & $4,313,341.13$ & $414,080,748.00$ \\
\hline 36 & $366,633,995.63$ & $4,313,341.13$ & $362,320,654.50$ \\
\hline 48 & $314,873,902.13$ & $4,313,341.13$ & $310,560,561.00$ \\
\hline 60 & $263,113,808.63$ & $4,313,341.13$ & $258,800,467.50$ \\
\hline 72 & $211,353,715.13$ & $4,313,341.13$ & $207,040,374.00$ \\
\hline 84 & $159,593,621.63$ & $4,313,341.13$ & $155,280,280.50$ \\
\hline 96 & $107,833,528.13$ & $4,313,341.13$ & $103,520,187.00$ \\
\hline 108 & $56,073,434.63$ & $4,313,341.13$ & $51,760,093.50$ \\
\hline 120 & $4,313,341.13$ & $4,313,341.13$ & - \\
\hline & IRR & $14.49 \%$ & \\
\hline
\end{tabular}

Tabel 2 (Kasus Kedua) Salinan Tabel Perhitungan Dari Budi ditambah IRR

2) Menurut pengakuan Budi yang dibuktikan dengan tampilan foto dokumen, bahwa metode pengakuan keuntungan yang diterapkan Bank Syariah ini adalah Flat.

3) Surat Resmi dari Bank Syariah menyatakan jumlah pelunasan sebelum jatuh tempo atau pelunasan dipercepat yang harus dibayar oleh Budi di bulan ke-24 adalah sebesar Rp 269.182.566,00 sudah termasuk biaya administrasi penutupan rekening sebesar Rp 15.000,00.

\section{PEMBAHASAN}

\subsection{Studi Kasus Pertama}

Bank Syariah berpotensi melakukan praktik bisnis yang mencederai asas manfaat dalam perlindungan konsumen sektor jasa keuangan Syariah dengan 2 (dua) pertimbangan. Pertama adalah pertimbangan Kualitatif dengan menggunakan 'urf tujjar atau kebiasaan umum Perbankan dalam pelunasan sebelum jatuh tempo pembiayaan atau kredit.

Berdasarkan hasil wawancara dengan 9 (praktisi) Bank Syariah, pelunasan KPR iB setelah jangka waktu tertentu tidak dikenakan pinalti, melainkan hanya melunasi pokok pembiayaan dengan tambahan 1 sampai dengan 3 kali margin (anuitas). Sedangkan, Standar Operasional Prosedur (SOP) KPR salah satu Bank Konvensional di wilayah Jakarta, ditemukan ketentuan yang mengatur bahwa kewajiban pelunasan setelah melewati 12 bulan atau lebih dari 12 kali angsuran hanya pokok kredit tanpa pinalti. Pinalti sebesar $1 \%$ dari sisa kredit dikenakan untuk pelunasan sebelum 12 bulan atau kurang dari 12 kali angsuran. 
Pembebanan keseluruhan sisa piutang murabahah saat terjadi pelunasan sebelum jatuh tempo KPR iB, tidak diragukan lagi telah menyelisihi kebiasaan umum yang berlaku di Perbankan (Syariah dan Konvensional) sehingga berpotensi merugikan Nasabah KPR iB (baca : Andi). 'Urf Tujjar atau kebiasaan umum Perbankan dalam transaksi keuangan (Syariah dan Konvensional) diakui eksistensinya sebagaimana dinyatakan pada pasal 1339 Kitab Undang-Undang Hukum Perdata atau KUH Perdata "Persetujuan tidak hanya mengikat apa yang dengan tegas ditentukan di dalamnya, melainkan juga segala sesuatu yang menurut sifat persetujuan dituntut berdasarkan keadilan, kebiasaan atau undang-undang”.

Kedua adalah pertimbangan kuantitatif dengan menggunakan Internal Rate of Return (selanjutnya disingkat 'IRR'). Simulasi perhitungan IRR dilakukan dengan menggunakan 3 skenario ;

a. Skenario 1 : jumlah kewajiban dengan pembebanan seluruh sisa harga jual (sisa pokok pembiayaan ditambah 169 kali margin).

b. Skenario 2 : jumlah kewajiban dengan pembebanan sisa pokok pembiayaan ditambah 3 kali margin (bulan ke 12,13 dan 14).

c. Skenario 3 : jumlah kewajiban yang mencerminkan asas manfaat.

Saat awal Akad Murabahah, secara tidak langsung Andi dan Bank Syariah telah menyepakati rate of return atau prosentasi tingkat keuntungan (selanjutnya singkat 'RR') adalah $13,25 \%$ efektif per tahun dengan metode pengakuan keuntungan Anuitas atau Thariqah al-Hisab al-Tanazuliyyah atau Thariqah alTanaqushiyyah. Jika Bank Syariah membebankan keseluruhan sisa harga jual, maka diperoleh RR baru berubah naik menjadi 90,37\%. Jika Bank Syariah membebankan 3 kali margin, maka diperoleh RR baru berubah naik menjadi 15,28\%. Jika Bank Syariah membebankan 1 kali margin, maka diperoleh RR baru yang tetap atau tidak berubah yaitu $13,25 \%$.

\begin{tabular}{|c|c|c|c|c|c|}
\hline \multicolumn{2}{|c|}{$\begin{array}{c}\text { Skenario } 1 \\
\text { (Seluruh Sisa Harga Jual) }\end{array}$} & \multicolumn{2}{|c|}{$\begin{array}{c}\text { Skenario } 2 \\
\text { (Sisa Pokok }+3 \text { Kali Margin) }\end{array}$} & \multicolumn{2}{|c|}{$\begin{array}{c}\text { Skenario 3 } \\
\text { (Mencerminkan Azas Manfaat) }\end{array}$} \\
\hline Bulan & $(380,000,000.00)$ & Bulan & $(380,000,000.00)$ & Bulan & $(380,000,000.00)$ \\
\hline 1 & $4,870,598.44$ & 1 & $4,870,598.44$ & 1 & $4,870,598.44$ \\
\hline 2 & $4,870,598.44$ & 2 & $4,870,598.44$ & 2 & $4,870,598.44$ \\
\hline 3 & $4,870,598.44$ & 3 & $4,870,598.44$ & 3 & $4,870,598.44$ \\
\hline 4 & $4,870,598.44$ & 4 & $4,870,598.44$ & 4 & $4,870,598.44$ \\
\hline 5 & $4,870,598.44$ & 5 & $4,870,598.44$ & 5 & $4,870,598.44$ \\
\hline 6 & $4,870,598.44$ & 6 & $4,870,598.44$ & 6 & $4,870,598.44$ \\
\hline 7 & $4,870,598.44$ & 7 & $4,870,598.44$ & 7 & $4,870,598.44$ \\
\hline 8 & $4,870,598.44$ & 8 & $4,870,598.44$ & 8 & $4,870,598.44$ \\
\hline 9 & $4,870,598.44$ & 9 & $4,870,598.44$ & 9 & $4,870,598.44$ \\
\hline 10 & $4,870,598.44$ & 10 & $4,870,598.44$ & 10 & $4,870,598.44$ \\
\hline 11 & $4,870,598.44$ & 11 & $4,870,598.44$ & 11 & $4,870,598.44$ \\
\hline 12 & $823,131,136.31$ & 12 & $384,456,210.86$ & 12 & $376,263,125.83$ \\
\hline TRR & $90.37 \%$ & TRR & $15.28 \%$ & TRR & $13.25 \%$ \\
\hline Pokok & $372,153,926.22$ & Pokok & $372,153,926.22$ & Pokok & $372,153,926.22$ \\
\hline Margin & $450,977,210.09$ & Margin & $12,302,284.64$ & Margin & $4,109,199.60$ \\
\hline Kewajiban PSJT & $823,131,136.31$ & Kewajiban PSJT & $384,456,210.86$ & Kewajiban PSJT & $376,263,125.83$ \\
\hline 169 & Kali Margin & $\overline{3}$ & Margin & 1 & $\operatorname{gin}$ \\
\hline
\end{tabular}

Tabel 3 (Kasus Pertama) Simulasi Perhitungan Kewajiban Pelunasan KPR iB Andi

Dari simulasi ini, tidak diragukan lagi bahwa skenario pertama dan kedua telah mencederai asas manfaat dalam perlindungan konsumen sektor jasa keuangan Syariah dari sisi konsumen. Walaupun tidak terdapat dalam perjanJIAn pembiayaan, seharusnya jumlah pelunasan sebelum jatuh tempo pembiayaan tetap mempertimbangkan RR efektif awal sebagaimana skenario ketiga bukan hanya 
mempertimbangkan nilai nominal absolut sisa piutang murabahah yang telah disepakati.

Kesimpulan Kasus Pertama, bahwa jumlah pelunasan sebelum jatuh tempo KPR iB dengan metode pengakuan keuntungan anuitas yang mencerminkan asas manfaat adalah sebesar Rp 376.263.125,83. Nilai tersebut diperoleh dari penjumlahan antara sisa pokok pembiayaan di bulan ke-11 sebesar Rp 372.153.926,22 dan 1 kali margin di bulan ke-12 sebesar Rp 4.109.199,60. Adapun potongan pelunasan yang seharusnya diberikan Bank Syariah kepada Andi sebagai discount adalah sebesar Rp 446.868.010,49.

\subsection{Studi Kasus Kedua}

Dengan menggunakan instrumen IRR, jumlah pelunasan sebesar Rp 269.182.566,00 oleh Bank Syariah berpotensi merugikan Budi. Berikut 3 skenario simulasi perhitungan IRR ;

a. Skenario 1: jumlah kewajiban sesuai Surat Resmi Bank Syariah sebesar Rp 269.182.566,00.

b. Skenario 2 : jumlah kewajiban dengan pembebanan sisa pokok pembiayaan ditambah 1 kali margin.

c. Skenario 3 : jumlah kewajiban yang mencerminkan asas manfaat.

Saat awal Akad Murabahah, secara tidak langsung Andi dan Bank Syariah telah menyepakati RR adalah 14,49 \% efektif per tahun. Angka RR efektif tersebut setara dengan $8,99 \%$ flat atau metode pengakuan keuntungan Flat atau Proporsional atau Thariqah Mubasyirah. Penggunaan asumsi RR efektif dipilih dengan 2 pertimbangan ; karakteristik efektif dan fungsi Bank Syariah sebagai lembaga intermediary (Penghimpun dan Penyalur Dana).

Karakteristik efektif adalah perhitungan keuntungan dilakukan dengan memperhatikan saldo pokok setiap bulan. Penting ditegaskan kembali, Bank Syariah sebagai lembaga intermediary melakukan perhitungan keuntungan untuk sisi penghimpunan dana dengan memperhatikan saldo simpanan atau investasi nasabah dana. ${ }^{14}$ Oleh sebab itu, RR efektif tepat dijadikan ukuran. Di antara 3 metode pengakuan keuntungan hanya Efektif dan Anuitas yang menggunakan saldo pokok sebagai unsur pengali keuntungan.

Jika Bank Syariah membebankan Rp 269.182.566,00, maka diperoleh RR efektif baru berubah naik menjadi 17,80\%. Jika Bank Syariah membebankan 1 kali margin, maka diperoleh RR efektif baru berubah turun menjadi 9,91\%. Jika Bank Syariah membebankan Rp 248.625.025.49, maka diperoleh RR efektif baru yang tetap atau tidak berubah yaitu 14,49\%. Dari simulasi ini, tidak diragukan lagi bahwa skenario pertama telah mencederai asas manfaat dari sisi konsumen yaitu Budi.

Skenario pertama dapat dinyatakan tidak mencederai asas manfaat, hanya jika Nasabah mengetahui di awal bahwa nilai RR efektif dari perhitungan KPR iB adalah $17,89 \%$ efektif per tahun. Skenario kedua juga telah mencederai asas manfaat dari sisi pelaku usaha, yaitu Bank Syariah. Sebagaimana paragraf sebelumnya bahwa Bank Syariah sebagai lembaga intermediary melakukan

14 Ikatan Bankir Indonesia. (2015). Mengelola Bisnis Pembiayaan Bank Syariah - Modul Sertifikasi Pembiayaan Syariah I. Jakarta. PT Gramedia Pustaka Utama. hal 146 dan 156 
perhitungan keuntungan untuk sisi penghimpunan dana dengan memperhatikan saldo simpanan atau investasi nasabah dana. Jika terjadi penurunan tingkat keuntungan dari kegiatan penyaluran dana (pembiayaan), maka Bank Syariah terekspose Risiko Imbal Hasil dan ini tentu merugikan Bank Syariah sebagai pelaku usaha.

Walaupun tidak terdapat dalam perjanJIAn pembiayaan, seharusnya perhitungan kewajiban pelunasan sebelum jatuh tempo pembiayaan tetap mempertimbangkan RR efektif awal sebagaimana skenario ketiga. Bukan hanya mempertimbangkan nilai nominal absolut sisa piutang murabahah yang telah disepakati.

\begin{tabular}{|c|c|c|c|c|c|}
\hline \multicolumn{2}{|c|}{$\begin{array}{c}\text { Skenario } 1 \\
\text { (Versi Bank Syariah) }\end{array}$} & \multicolumn{2}{|c|}{$\begin{array}{c}\text { Skenario } 2 \\
\text { (Sisa Pokok }+1 \text { Kali Marjin) }\end{array}$} & \multicolumn{2}{|c|}{$\begin{array}{c}\text { Skenario } \\
\text { (Mencerminkan Azas Manfaat) }\end{array}$} \\
\hline Bulan & $(272,565,000.00)$ & Bulan & $(272,565,000.00)$ & Bulan & $(272,565,000.00)$ \\
\hline 1 & $4,313,341.13$ & 1 & $4,313,341.13$ & 1 & $4,313,341.13$ \\
\hline 2 & $4,313,341.13$ & 2 & $4,313,341.13$ & 2 & $4,313,341.13$ \\
\hline 3 & $4,313,341.13$ & 3 & $4,313,341.13$ & 3 & $4,313,341.13$ \\
\hline 4 & $4,313,341.13$ & 4 & $4,313,341.13$ & 4 & $4,313,341.13$ \\
\hline 5 & $4,313,341.13$ & 5 & $4,313,341.13$ & 5 & $4,313,341.13$ \\
\hline 6 & $4,313,341.13$ & 6 & $4,313,341.13$ & 6 & $4,313,341.13$ \\
\hline 7 & $4,313,341.13$ & 7 & $4,313,341.13$ & 7 & $4,313,341.13$ \\
\hline 8 & $4,313,341.13$ & 8 & $4,313,341.13$ & 8 & $4,313,341.13$ \\
\hline 9 & $4,313,341.13$ & 9 & $4,313,341.13$ & 9 & $4,313,341.13$ \\
\hline 10 & $4,313,341.13$ & 10 & $4,313,341.13$ & 10 & $4,313,341.13$ \\
\hline 11 & $4,313,341.13$ & 11 & $4,313,341.13$ & 11 & $4,313,341.13$ \\
\hline 12 & $4,313,341.13$ & 12 & $4,313,341.13$ & 12 & $4,313,341.13$ \\
\hline 13 & $4,313,341.13$ & 13 & $4,313,341.13$ & 13 & $4,313,341.13$ \\
\hline 14 & $4,313,341.13$ & 14 & $4,313,341.13$ & 14 & $4,313,341.13$ \\
\hline 15 & $4,313,341.13$ & 15 & $4,313,341.13$ & 15 & $4,313,341.13$ \\
\hline 16 & $4,313,341.13$ & 16 & $4,313,341.13$ & 16 & $4,313,341.13$ \\
\hline 17 & $4,313,341.13$ & 17 & $4,313,341.13$ & 17 & $4,313,341.13$ \\
\hline 18 & $4,313,341.13$ & 18 & $4,313,341.13$ & 18 & $4,313,341.13$ \\
\hline 19 & $4,313,341.13$ & 19 & $4,313,341.13$ & 19 & $4,313,341.13$ \\
\hline 20 & $4,313,341.13$ & 20 & $4,313,341.13$ & 20 & $4,313,341.13$ \\
\hline 21 & $4,313,341.13$ & 21 & $4,313,341.13$ & 21 & $4,313,341.13$ \\
\hline 22 & $4,313,341.13$ & 22 & $4,313,341.13$ & 22 & $4,313,341.13$ \\
\hline 23 & $4,313,341.13$ & 23 & $4,313,341.13$ & 23 & $4,313,341.13$ \\
\hline 24 & $269,182,566.00$ & 24 & $222,365,341.13$ & 24 & $248,625,025.49$ \\
\hline IRR & $17.80 \%$ & IRR & $9.91 \%$ & \begin{tabular}{l|l|} 
IRR & \\
\end{tabular} & $14.49 \%$ \\
\hline Pokok & - & Pokok & $220,323,375.00$ & Pokok & $220,323,375.00$ \\
\hline Marjin & - & Marjin & $2,041,966.13$ & Marjin & $28,301,650.49$ \\
\hline jiban PSJT & - & vajiban PSJT & $222,365,341.13$ & Kewajiban PSJT & $248,625,025.49$ \\
\hline 23.92 & Kali Margin & 1.00 & Kali Marjin & 13.86 & Kali Marjin \\
\hline
\end{tabular}

Tabel 4 (Kasus Kedua) Simulasi Perhitungan Kewajiban Pelunasan KPR iB Budi

Kesimpulan Kasus Kedua bahwa jumlah pelunasan sebelum jatuh tempo KPR iB dengan metode pengakuan keuntungan flat atau proporsional yang mencerminkan asas manfaat adalah sebesar Rp 248.625.025,49. Nilai tersebut diperoleh dari penjumlahan antara sisa pokok pembiayaan di bulan ke-23 sebesar Rp 220.323.375,00 dan margin di bulan ke-12 s/d bulan ke-25 (13,86 kali) sebesar Rp 28.301.650,49. Adapun potongan pelunasan yang seharusnya diberikan Bank Syariah kepada Budi sebagai discount adalah sebesar Rp 169.769.063,63.

\subsection{KPR iB Kualitas Rendah}

KPR iB Kualitas Rendah berarti pembiayaan properti yang memiliki riwayat keterlambatan pembayaran angsuran. Pada kondisi KPR iB Kualitas Rendah, dimungkinkan RR efektif baru akan lebih rendah dari RR efektif awal. Pada KPR iB Kualitas Macet kemungkinan itu berubah menjadi kepastian. Salah satu cara menaikkan nilai RR efektif adalah dengan menambah jumlah kas. Akan tetapi, 
sampai dengan kondisi tertentu alokasi kas masuk yang dapat digunakan (pokok dan margin) akan mencapai batas akhir. Batas akhir adalah kondisi dimana jumlah seluruh alokasi kas (nilai nominal absolut) sudah maksimal sebagaimana disepakati pada awal perjanJIAn murabahah. Setiap penambahan jumlah margin yang melampaui nilai nominal absolut dari piutang murabahah adalah Riba. ${ }^{15}$

\subsection{Mewujudkan Asas Keadilan Kepada Nasabah KPR iB Berprestasi}

DR. Oni Sahroni, dalam Ushul Fikih Muamalah, menulis tentang konsep transaksi (keuangan) sebagaimana dikutip dari penelitian Matthew Rabin yang berjudul Incorporating Fairness into Game Theory and Economics. Matthew Rabin menyebutkan dalam setiap transaksi ada dua kesepakatan yang harus terpenuhi, yaitu Kesepakatan Pasar (market equlibria) dan Kesepakatan Rasa Keadilan (fairness equlibria). Kesepakatan antara perusahaan besar dengan para pelanggan kecil yang merasa terekploitasi merupakan contoh tidak tercapainya kesepakatan rasa keadilan. Para pelanggan kecil karena tidak punya pilihan lain mereka harus menerima kesepakatan pasar dari perusahaan besar. Transaksi ini tidak akan stabil atau berkelanjutan dan cenderung rapuh karena konsumen merasa tidak nyaman. Ketika ada pilihan lain yang dapat memberikan rasa keadilan walaupun kadang belum tentu lebih baik maka mereka tetap akan berpindah. ${ }^{16}$

Praktik bisnis keuangan syariah harus mampu menerapkan keadilan untuk kepentingan konsumen (nasabah) dan pelaku usaha (bank syariah). Keadilan berarti kepentingan konsumen dan pelaku usaha dapat diwujudkan secara maksimal dan memberikan kesempatan kepada mereka kesempatan untuk memperoleh hak dan melaksanakan kewajiban masing-masing secara adil. Inilah yang dimaksud dengan asas keadilan sebagaimana diamanahkan Undang-Undang Perlindungan Konsumen.

Berdasarkan wawancara dengan sejumlah Praktisi Bank Syariah, secara umum mereka menerima konsep pelunasan sebelum jatuh tempo yang mencerminkan asas manfaat. Akan tetapi, mereka belum berkenan menerapkannya ke dalam Dokumen Administrasi Pembiayaan atas dasar pertimbangan Syariah dan Bisnis. Terkait pertimbangan Syariah akan dianalisis pada sub pembahasan berikutnya.

Sebagian besar Praktisi Bank Syariah menjawab bahwa motif pelunasan sebelum jatuh tempo bukan untuk menyelesaikan pembiayaan, melainkan berpindah Bank. Itulah pertimbangan yang dikelompokkan sebagai motif bisnis dari Nasabah dalam perspektif praktisi yang menjadi responden. Motif lain adalah mempercepat jangka waktu pembiayaan dan menurunkan angsuran. Dua motif terakhir ini dikategorikan sebagai pelunasan sebagian dari pembiayaan. Berangkat dari perspektif motif berpindah Bank, maka sasaran penerapan kebijakan ini

15 Muhammad ibn Isma'il al-Amiri al-Yamin Shan’ani.(2000). Subulussalam, Jil. 3. Kairo. Darul Hadits. hal 71

16 Oni Sahroni. (2017). Ushul Fikih Muamalah ; Kaidah-Kaidah Ijtihad dan Fatwa Dalam Ekonomi Islam. Jakarta. Rajawali Press. hal 118 
adalah Nasabah KPR iB dengan kriteria Berprestasi. Hal ini dapat menjadi tawaran solusi bagi Bank Syariah.

Kriteria 'Berprestasi' adalah Nasabah KPR iB dengan riwayat pembiayaan berkualitas lancar dan/atau dengan kemampuan dana mandiri yang ingin melakukan pelunasan sebelum jatuh tempo KPR untuk menyelesaikan kewajiban pembiayaan. Riwayat kualitas pembiayaan lancar merupakan prestasi. Sedangkan, riwayat pembiayaan berkualitas rendah dapat dikategorikan tidak berprestasi. Menyelesaikan kewajiban pembiayaan dengan sumber dana dari kemampuan usaha mandiri merupakan prestasi yang harus dihargai oleh Bank Syariah. Sedangkan, menyelesaikan pembiayaan dengan sumber dana dari Perbankan atau Lembaga Keuangan lain bukanlah suatu prestasi.

Solusi ini ditawarkan dengan beberapa pertimbangan. Pertama, motif berpindah Bank merupakan fakta yang harus disikapi secara tepat. Misalnya, dengan mencari solusi titik tengah 'win-win solution' antara manfaat bagi konsumen dan manfaat bagi pelaku usaha. Pengabaian motif ini akan mengakibatkan inovasi dalam persaingan bisnis keuangan Syariah hanya berporos kepada 'Perang Harga'. Penelitian ini bukan ditujukan untuk memperkeruh kondisi persaingan Bank Syariah. Kedua, Nasabah KPR iB harus memahami bahwa tuntutan Islam tentang hutang adalah anjuran untuk segera melunasinya. Islam tidak pernah mengajarkan seorang Muslim menambah hutang untuk melunasi hutang dan/atau berhutang untuk melunasi hutang. DR. Yusuf Qardhawi menulis bahwa Islam mewajibkan sikap adil dengan melunasi hutang jika sudah sanggup membayar. Jika seseorang mampu membayar hutang tetapi ia tidak melakukannya maka ia bertindak zalim. Berdasarkan hadits shahih ${ }^{17}$ yang diriwayatkan dari Jamaah ini dari Abu Hurairah Nabi shallallahu 'alaihi wa sallam bersabda ; "Penundaan Pembayaran hutang oleh orang kaya adalah kezaliman." 18

Ketiga, implementasi kebijakan pelunasan sebelum jatuh tempo dengan sasaran kriteria 'Berprestasi', secara tidak langsung dapat menjadi pemicu semangat produktifitas ekonomi Nasabah KPR iB. Ini penting untuk peningkatan ekonomi Nasional yang menjadi salah satu tujuan bisnis keuangan Syariah secara makro. Ke-empat, Nasabah KPR iB Berprestasi yang mendapatkan keadilan dalam pelunasan sebelum jatuh tempo, bukan tidak mungkin akan menjadi Nasabah Prima dan Loyal bagi Bank Syariah tersebut. Ini adalah dampak dari tercapainya 2 (dua) kesepakatan dalam bisnis keuangan Syariah yaitu kesepakatan harga dan kesepakatan rasa keadilan sebagaimana penelitian Matthew Rabin.

Asas keadilan atau prinsip perlakuan yang adil dapat diterjemahkan dengan menerapkan kebijakan pelunasan sebelum jatuh tempo yang mencerminkan asas manfaat oleh Bank Syariah. Langkah yang dilakukan adalah pengaturan pada Buku Pedoman Produk. Pokok pengaturan kebijakan pelunasan sebelum jatuh tempo meliputi ; Definisi, Kriteria, serta Metode Pelunasan.

\footnotetext{
${ }^{17}$ Muhammad Nashiruddin Al-Bâni. (1988). Shahih al-Jâmi' al-Shaghir wa Ziyâdah al-Fathu alkabîr, jil 2. Beirut. al-Maktabah al-Islâmy. hal 1022

${ }^{18}$ Yusuf Qardhawi. (2001). Daurul Qiyam Wal Akhlaq Fil Iqtishadil Islami ; Norma dan Etika Ekonomi Islam. Penerjemah Zainul Arifin. Jakarta. Gema Insani Press. hal 188
} 


\subsection{Implementasi Klausul Pelunasan Sebelum Jatuh Tempo KPR iB Dalam Dokumen Administrasi Pembiayaan}

Otoritas Jasa Keuangan dan AAOIFI membolehkan secara bersyarat, jika Bank Syariah ingin memberikan potongan pelunasan kepada Nasabah. Keduanya mensyaratkan bahwa potongan pelunasan tidak boleh diperjanjikan dalam Akad atau PerjanJIAn Pembiayaan. Dikutip dari Harta Haram Muamalat Kontemporer DR. Erwandi Tarmizi menjelaskan bahwa pelarangan pencantuman potongan pelunasan dalam akad atau perjanJIAn pembiayaan untuk menghindari terjadinya ketidakjelasan harga transaksi.

Dalam analisis lain, Azharuddin Latief, S.Ag, SH, M.Ag, MH responden dari unsur DSN-MUI juga berpendapat ketidakjelasan harga akan terjadi jika potongan pelunasan diperjanjikan dalam akad. Beliau menambahkan bahwa ; $i$ ) potongan pelunasan (murabahah) bukan soal keadilan (baca : asas manfaat) melainkan nilai kompetitif persaingan Bank Syariah, ii) keadilan dalam murabahah sudah terjadi di saat Nasabah menyepakati jangka waktunya dan Bank pun menghitung keuntungan dengan jangka waktu yang sama, iii) fatwa DSN-MUI No.85/DSNMUI/XII/2012 berfungsi sebagai penegasan konsep janji pada fatwa lainnya; line facility, Murabahah, IMBT atau untuk konsep Sukuk. Fatwa itu bukan untuk mengakomodir janji potongan pelunasan murabahah dan $i v$ ) janji pelunasan tidak bisa dibuat saat penandatangan akad (di depan). ${ }^{19}$ Responden lain dari unsur Otoritas Jasa Keuangan menyatakan bahwa ; "Sebagaimana tertuang dalam fatwa DSN-MUI No.23/DSN-MUI/III/2002 tentang Potongan Pelunasan Dalam Murabahah, Bank Syariah boleh memberikan potongan dari kewajiban pembayaran atas akad murabahah dengan syarat tidak diperjanjikan dalam akad dan besar potongan sebagaimana dimaksud diatas diserahkan kepada internal Bank Syariah. Dengan merujuk kepada ketentuan tersebut, tentunya pemberian potongan pelunasan dipercepat KPR iB tidak dapat diperjanjikan di awal baik melalui akad pembiayaan maupun tertuang dalam dokumen terpisah dari akad, dimana sebenarnya dokumen tersebut mengikat kedua pihak dan tidak dapat dipisahkan dari akad pembiayaan."

Advokat Ekonomi Syariah, Mustolih Siradj, SHI, MA, CLA responden dari unsur Asosiasi Pengacara Syariah, menyatakan persoalan pelunasan sebelum jatuh tempo sulit jika dianalisis dari hubungan kontraktual. Kontrak (perjanJIAn) antara Nasabah dan Bank Syariah merupakan kesepakatan dengan kekuatan mengikat sebagaimana undang-undang (pasal 1338 KUH Perdata). Namun demikian, jika ditemukan informasi dari dokumen apapun (di luar perjanJIAn pembiayaan) yang memungkinkan untuk ditafsirkan (berdasarkan 'urf tujjar) sebagai janji atau peluang Bank kepada Nasabah, maka Nasabah dapat diberikan pembelaan. Pembelaan dimaksud ditempuh melalui jalur perbuatan melawan hukum (hukum perlindungan konsumen atau pidana) bukan dari jalur gugatan wan prestasi (hubungan kontraktual atau perdata). ${ }^{20}$ Responden lain, A.M Hasan Ali, MA, Ketua Program Studi Hukum Ekonomi Syariah Fakultas Syariah dan Hukum UIN Syarif Hidayatullah, menyatakan bahwa ; "Janji dapat dibunyikan dalam klausula kontrak yang disepakati”.

\footnotetext{
${ }^{19}$ Intisari Wawancara di kediaman Beliau pada tanggal 10 Desember 2017

${ }^{20}$ Intisari Wawancara dengan Beliau pada tanggal 11 November 2017
} 
Penerapan kebijakan pelunasan jatuh tempo dalam dokumen administrasi pembiayaan dapat dilakukan dengan 2 alternatif, yaitu $i$ ) pembuatan janji pada dokumen yang terpisah dari PerjanJIAn Pembiayaan dan ii) penambahan informasi pada PerjanJIAn Pembiayaan atau lampirannya. Alternatif pertama dibuat dengan pertimbangan bahwa OJK, AAOIFI dan DSN-MUI membolehkan Bank Syariah untuk memberikan potongan pelunasan selama tidak diperjanjikan dalam Akad atau PerjanJIAn Pembiayaan. Pendapat yang menyatakan bahwa janji pelunasan tidak dapat dibuat saat penandatangan akad (di depan) tidak memiliki alasan yang kuat. Tidak ada larangan tegas berkaitan dengan pembuatan janji bersamaan dengan perjanJIAn pembiayaan. Kebebasan melakukan transaksi ekonomi sangat dihargai dalam Islam sepanjang tidak ditemukan larangannya. Inilah kaidah utama Muamalah ${ }^{21}$. Kekhawatiran terjadinya ketidakjelasan atau gharar pada harga murabahah menjadi hilang karena janji dibuat dalam dokumen terpisah. Wa'd sebanding dengan janji atau pernyataan pihak tentang kesanggupan untuk melakukan sesuatu atau tidak melakukan perbuatan tertentu. Sedangkan akad sepadan dengan perjanJIAn. ${ }^{22}$

Alternatif kedua bukanlah janji, melainkan penambahan informasi. Akad Murabahah adalah transaksi jual beli dimana penjual harus memberitahukan secara tegas informasi harga awal dan keuntungan kepada Pembeli. Jika dalam praktik umumnya hanya dinyatakan harga perolehan dan keuntungan, maka guna mencapai maksud penelitian pernyataan harus ditambah dengan ; metode pengakuan keuntungan pada pasal definisi di perjanJIAn pembiayaan dan informasi angka persentasi yang digunakan saat menghitung angsuran pada lembar tabel angsuran yang menjadi lampiran akad.

\section{KESIMPULAN}

Praktik bisnis keuangan syariah harus mampu memberikan manfaat sebesarbesarnya untuk kepentingan konsumen (nasabah) dan pelaku usaha (bank syariah). Inilah yang dimaksud dengan asas manfaat sebagaimana diamanahkan dalam Undang-Undang Perlindungan Konsumen. Dalam persoalan pelunasan sebelum jatuh tempo pembiayaan, asas manfaat dapat diterjemahkan dengan menawarkan jumlah pelunasan yang meringankan Nasabah dan tidak merugikan Bank Syariah. Hal tersebut dapat diwujudkan dengan memilih metode perhitungan yang tepat. Perhitungan jumlah pelunasan sebelum jatuh tempo pembiayaan dapat dilakukan dengan menggunakan instrumen Internal Rate of Return atau IRR. Metode perhitungan yang mencerminkan asas manfaat adalah dengan pola saldo pokok dimana nilai Rate of Return atau RR efektif saat pelunasan harus sama dengan RR efektif awal.

Pada kasus KPR iB dengan metode pengakuan keuntungan Anuitas dan Flat atau Proporsional, RR efektif tepat dijadikan ukuran. Sebab, Bank Syariah melakukan perhitungan keuntungan untuk sisi penghimpunan dana dengan memperhatikan saldo simpanan atau investasi nasabah dana yang merupakan

\footnotetext{
${ }^{21}$ Oni Sahroni, Hasanuddin. Op. Cit. hal 15

22 Jaih Mubarok. Loc.Cit.
} 
karakteristik RR efektif. Sedangkan, pada kasus KPR iB Kualitas Rendah, teknik menyamakan nilai RR efektif baru dan RR efektif awal harus memperhatikan batas akhir nilai nominal absolut piutang murabahah yang telah disepakati pada awal perjanJIAn. Tidak dibenarkan melakukan penambahan nilai nominal arus kas untuk menaikkan angka RR efektif hasil perhitungan. Sebab, penambahan itu adalah Riba.

Dalam persoalan pelunasan sebelum jatuh tempo pembiayaan, asas keadilan atau prinsip perlakuan adil dapat diterjemahkan dengan mengimplementasikan kebijakan pelunasann sebelum jatuh tempo yang mencerminkan asas manfaat. Kriteria Nasabah KPR iB Berprestasi adalah riwayat pembiayaan lancar dan/atau melunasi pembiayaan dengan kemampuan dana mandiri. Inilah yang menjadi sasaran implementasi kebijakan tersebut. Implementasi tersebut diharapkan dapat menyeimbangkan posisi tawar Nasabah KPR iB Berprestasi dengan Bank Syariah.

Media implementasinya adalah Buku Pedoman Produk (BPP) dan Dokumen Administrasi Pembiayaan. Pokok pengaturan kebijakan pelunasan jatuh sebelum jatuh tempo pada Buku Pedoman Produk Bank Syariah meliputi ; Definisi, Kriteria, serta Metode Pelunasan. Sedangkan, pada Dokumen Administrasi Pembiayaan dapat dilakukan dengan 2 alternatif, yaitu ; i) pembuatan janji pada dokumen yang terpisah dari PerjanJIAn Pembiayaan dan ii) penambahan informasi pada PerjanJIAn Pembiayaan atau lampirannya.

\subsection{Implikasi dan Keterbatasan}

Hasil Penelitian hanya direkomendasikan untuk Pembiayaan Properti Skema Murabahah atas dasar pesanan bukan atas dasar persediaan. Hal tersebut menjadi keterbatasan dari penelitian ini. Pembiayaan Properti Skema Murabahah Persediaan memiliki karakteristik risiko yang berbeda. Berkaitan dengan perhitungan jumlah pelunasan untuk skema ini, terbuka peluang untuk dilakukan kaJIAn risiko yang lebih dalam sehingga menghasilkan kesimpulan penelitian yang tepat, tidak merugikan Bank dan Nasabah.

\section{DAFTAR PUSTAKA}

Accounting and Auditing Organization for Islamic Financial Institutions. (2015). Shari'a Standards. Kingdom of Bahrain.

Al-Bâni, Muhammad Nashiruddin. (1988). Shahih al-Jâmi' al-Shaghir wa Ziyâdah al-Fathu al-kabîr. Jil. 1 \& 2. Beirut. al-Maktabah al-Islâmy.

Al-Qardhawi, Yusuf. (2014. Kaidah Utama Fikih Muamalah. Penerjemah Fedrian Hasmand. Jakarta. Pustaka Al-Kautsar.

Al-Qardhawi, Yusuf. (2001). Norma dan Etika Ekonomi Islam. Penerjemah Zainul Arifin. Jakarta. Gema Insani Press

Al-Zuhaili, Wahbah. (2008). Al-Fiqh Al-islami Wa Adillatuhu, Juz 4. Damaskus. Dar Fikr al-Mu' asir.

Budianto, Aris. (2007). Modul Praktikum KKPI Microsoft Excel 2007 - Untuk Kelas : X Semester 2. Sidareja. SMK Tamtama 1 Sidareja. 
Ikatan Bankir Indonesia. (2014). Memahami Bank Syariah - Modul Sertifikasi Tingkat I General Banking Syariah. Jakarta. PT Gramedia Pustaka Utama.

Ikatan Bankir Indonesia. (2014). Mengelola Bank Syariah - Modul Sertifikasi Tingkat II General Banking Syariah. Jakarta : PT Gramedia Pustaka Utama.

Ikatan Bankir Indonesia. (2015). Strategi Bisnis Bank Syariah - Modul Sertifikasi General Banking Syariah III. Jakarta. PT Gramedia Pustaka Utama.

Ikatan Bankir Indonesia. (2015). Mengelola Bisnis Pembiayaan Bank Syariah Modul Sertifikasi Pembiayaan Syariah I. Jakarta. PT Gramedia Pustaka Utama.

Mubarok, Jaih, Hasanudin. (2017). Fikih Mu'amalah Maliyyah - Jilid PrinsipPrinsip PerjanJIAn. Bandung. Simbiosa Rekatama Media.

Mubarok, Jaih, Hasanudin. (2017). Fikih Mu'amalah Maliyyah - Jilid Akad Jual Beli. Bandung : Simbiosa Rekatama Media.

Muslich, Mohamad. (tth). Manajemen Keuangan Modern ; Analisis, Perencanaan dan Kebijaksanaan. Jakarta. PT Bumi Aksara.

Moleong, Lexy.J. (2006). Metode Penelitian Kualitatif, (Eds). Bandung. PT Remaja Rosda Karya.

Otoritas Jasa Keuangan. (2016). Standar Produk Murabahah. Jakarta

Sabiq, Sayyid. (2008). Fiqhus Sunnah. Penerjemah Asep Sobari, Muhil Dhofir, Sofwan Abbas \& Amir Hamzah. Jakarta. Al-I'tishom Cahaya Umat.

Sahroni, Oni. (2017). Ushul Fikih Muamalah ; Kaidah-Kaidah Ijtihad dan Fatwa Dalam Ekonomi Islam. Jakarta. Rajawali Press.

Sahroni, Oni, Hasanuddin. (2016). Fikih Muamalah ; Dinamika Teori Akad dan Implementasinya dalam Ekonomi Syariah. Jakarta. Rajawali Press.

Sahroni, Oni, Adiwarman A. Karim. (2017). Maqashid Bisnis \& Keuangan Islam ; Sintesa Fikih dan Ekonomi. Jakarta. Rajawali Press.

Salam, Syamsir dan Jaenal Aripin. (2004). Metodologi Penelitian Sosial. Jakarta. UIN Jakarta Press.

Samsi, Harry. (2016). Ini Bukti Lingkaran Setan Kpr Bank. https://pospolitan.blogspot.co.id/2016/08/ini-bukti-lingkaran-setan-kpr-bank.html

San’ani, Muhammad ibn Isma'il al-Amiri al-Yamin. (2000). Subulussalam, Jil. 3, Kairo.Darul Hadits.

Soemitra, Andri. (2010). Bank \& Lembaga Keuangan Syariah. Jakarta. Kencana.

Supriyanto, Trisiladi. (2014). Konsep Rate of Profit Perspektif Ekonomi Islam. Disertasi S3. Sekolah Pasca Sarjana Universitas Islam Negeri Syarif Hidayatullah.

Tarmizi, Erwandi. (2016). Harta Haram Muamalat Kontemporer. Bogor. PT. Berkat Mulia Insani.

Walsh, Ciaran. (2012). Key Management Ratios Edisi Keempat.. Penerjemah Agus Dharma. Jakarta. Esensi Erlangga Group.

Widiyono, Try. (2009). Agunan Kredit Dalam Financial Engineering. Jakarta. Ghalia Indonesia. 